\title{
PENGARUH ARANG SEKAM PADI DAN PASIR KUARSA SEBAGAI BAHAN PENGISI TERHADAP KUALITAS KARET BANTALAN DERMAGA
}

\section{THE EFFECT OF RICE HUSK CHARCOAL AND QUARTZ SAN AS FILLING MATERIALS TOWARDS RUBBER DOCK FENDER QUALITY}

\author{
Tri Susanto* dan Rahmaniar * \\ *main contributors and corresponding author \\ *Balai Riset dan Standardisasi Industri Palembang, JI Perindustrian II No 12 KM 9, Sukarami, Palembang \\ e-mail : tri.susanto@kemenperin.go.id dan rahmaniar_een@yahoo.com
}

Diterima: 1 April 2019; Direvisi: 2019 - 25 Juli 2019; Disetujui: 30 Juli 2019

\begin{abstract}
Abstrak
Penelitian ini bertujuan untuk menemukan formulasi kompon karet bantalan dermaga yang memenuhi Standar Nasional Indonesia (SNI), dengan menggunakan variasi bahan pengisi dan konsentarsi bahan pengisi. Rancangan penelitian yang digunakan adalah Rancangan Acak Lengkap (RAL) dengan tiga kali pengulangan. Faktor pertama variasi bahan pengisi arang sekam padi $(A): A_{1}=40 \mathrm{phr}, A_{2}=50 \mathrm{phr}$ dan $A_{3}=60 \mathrm{phr}$. Faktor kedua yaitu bahan pengisi pasir kuarsa $(B): B_{1}=40 \mathrm{phr}, B_{2}=50 \mathrm{phr}$ dan $B_{3}=60$ phr. Pengujian mutu karakteristik kompon karet yaitu uji kekerasan, tegangan putus, perpanjangan putus dan ketahanan sobek. Hasil penelitian menunjukkan bahwa nilai karakteristik fisik kompon dengan hasil perlakuan terbaik terdapat pada formula $\mathrm{B}_{1}$. Variasi konsentrasi pasir kuarsa $40 \mathrm{phr}$ dengan nilai hasil uji yaitu kekerasan 54 shore $\mathrm{A}$, tegangan putus $16,67 \mathrm{~N} / \mathrm{mm}^{2}$, perpanjangan putus $620 \%$ dan ketahanan sobek 2,06 N/mm². Memenuhi syarat karet kompon bantalan dermaga SNI 06-3568-2006 kecuali parameter ketahanan sobek.

Kata kunci : kompon karet, bantalan dermaga, arang sekam padi, pasir kuarsa.
\end{abstract}

\begin{abstract}
This study aims to find the formulation of dock bearing compound rubber that meets the Indonesian National Standard (SNI), using a variety of fillers and concentrations of fillers. The research design used was a Completely Randomized Design (CRD) with three repetitions. The first factor is the variation of rice husk charcoal filler material (A): $A_{1}=40 \mathrm{phr}, A_{2}=50 \mathrm{phr}$ and $A_{3}=60 \mathrm{phr}$. The second factor is quartz sand filler material (B): $B_{1}=40 \mathrm{phr}, B_{2}=50$ $\mathrm{phr}$ and $B_{3}=60 \mathrm{phr}$. The quality testing of the characteristics of rubber compounds, namely hardness of breaking stress, elongation and tear resistance. The results showed that the value of the physical characteristics of the compound with the best treatment results were found in formula $B_{1}$ Variation in concentration of 40 phr quartz sand with test results of hardness 54 shore A, breaking stress $16.67 \mathrm{~N} / \mathrm{mm}^{2}$, breakout extension $620 \%$ and tear resistance $2,06 \mathrm{~N} / \mathrm{mm}^{2}$. Fulfill the requirements of dock bearing compound rubber SNI 06-3568-2006 except the tear resistance parameters.
\end{abstract}

Keywords: rubber compound, dock bearings, rice husk charcoal, quartz sand

\section{PENDAHULUAN}

Usaha-usaha dalam kegiatan penelitian untuk menggali sumber daya alam sebagai bahan baku maupun bahan tambahan untuk keperluan industri barang jadi karet sudah banyak dilakukan oleh para peneliti. Hal ini dikarenakan banyaknya industri yang memerlukan bahan baku dimana ketersediaannya mulai terbatas atau harganya makin meningkat. Makin tingginya harga bahan baku mengakibatkan biaya produksi meningkat dan mengakibatkan harga produk makin tinggi. Peningkatan ini tentunya seiring dengan semakin meningkatnya kebutuhan bahan baku karet atau barang jadi karet baik jumlah maupun jenis komponen karet yang dihasilkan. 
Tri Susanto Pengaruh Arang Sekam Padi dan Pasir Kuarsa Sebagai Bahan Pengisi Terhadap Kualitas Karet Bantalan

Pembuatan barang jadi karet diperlukan bahan tambahan yaitu filler atau bahan pengisi, dimana sebagian besar bahan pengisi masih di import dan harganya relative tinggi. Untuk menekan tingginya biaya produksi akibat tingginya harga bahanbahan kimia sebagai bahan pembuatan barang jadi karet, maka dicari alternative penggunaan bahan pengisi yang berasal dari bahan alami yang bersumber dari sumber daya alam lokal.

Penggunaan bahan pengisi dalam pembuatan kompon karet sangat diperlukan, hal ini dikarenakan bahan pengisi akan mempengaruhi sifat mekanik fisik vulkanisat produk. Menurut Frohlich et al, 2005, pemilihan bahan pengisi merupakan tahap yang penting setelah pemilihan karet dan proses vulkanisasi. Selain itu juga penggunaan bahan pengisi (filler) akan mempengaruhi biaya bahan, spesifikasi produk yang dihasilkan dan energi untuk memproduksinya (Ku et al, 2011).

Dalam pembuatan barang jadi karet, umumnya dikenal dua macam bahan pengisi yaitu bahan pengisi penguat (reinforcing) akan meningkatkan kekerasan barang jadi karet dan bahan pengisi non penguat akan memperbesar volume tanpa meningkatkan kekerasan maupun tensile propertiesnya ( $\mathrm{Fu}$, S-Y et al, 2008; Frohlich, et al, 2005; Leblanc, 2002).

Bahan pengisi pada umumnya diperoleh dari bahan yang tidak terbarukan, yaitu berasal dari bahan tambang atau bahan galian yang cadangannya makin lama makin berkurang. Oleh sebab itu penelitian bahan pengisi berbasis bahan terbarukan sangat diperlukan dalam rangka menggali sumber bahan pengisi baru untuk produk karet. Bahan pengisi yang bersumber dari sumber daya alam dapat diperkirakan menjadi alternative pengganti bahan pengisi minyak bumi. Penelitian ini menggunakan bahan pengisi arang sekam padi dan pasir kuarsa.

Arang sekam padi berasal dari residu kulit padi atau sekam padi, yang jumlahnya sekitar $20-25 \%$ dari berat kotor padi (Mor et al, 2016). Menurut Biro Pusat Statistik (2018), produksi padi di Indonesia lebih kurang 55 juta ton padi, yang menghasilkan sekam padi lebih kurang 13 juta ton per tahun. Sekam padi dimanfaatkan agar mempunyai nilai tambah, dapat menanggulangi masalah lingkungan, sehingga memberikan nilai ekonomis bagi masyarakat. Jika dilakukan pembakaran terhadap sekam padi pada suhu $400^{\circ} \mathrm{C}-500^{\circ} \mathrm{C}$, maka sekam padi akan menjadi silika amorphous, jika sekam padi dibakar pada suhu $>1000^{\circ} \mathrm{C}$ akan menjadi silika kristalin (Bakri, 2008). Silika kristalin dari sekam padi ini diduga dapat mensubstitusi karbon hitam meskipun belum dapat menyamai fungsi karbon hitam sebagai bahan pengisi penguat. Penggunaan bahan pengisi dari karbon hitam lebih efektif dalam mewujudkan kekerasan vulkanisat karet jika dibandingkan dengan penggunaan bahan pengisi dari silika, dimana silika memerlukan jumlah yang relatif dua kali lipat dari jumlah karbon hitam untuk menghasilkan nilai kekerasan yang sama (Rattanasom et al, 2009). Interaksi bahan pengisi dan karet dijelaskan oleh kesesuaian bahan pengisi dan karet, interaksi bahan pengisi sendiri mempunyai kemampuan untuk membentuk jaringan (Haghigat et al, 2007). Penelitian substitusi arang sekam padi sebagai filler telah banyak dilakukan seperti penggunaan arang silika sekam padi sebagai bahan pengisi kompon sol karet (Yuniari dan Lestari S.B.P, 2003).

Pasir kuarsa mengandung kristalkristal silika $\left(\mathrm{SiO}_{2}\right)$ berfungsi sebagai bahan pengisi (Hadi et al, 2010). Pasir kuarsa bersumber dari bahan galian, dikenal dengan nama pasir putih merupakan hasil pelapukan batuan. Hasil pelapukan kemudian tercuci dan terbawa oleh air atau angin yang terendapkan ditepi-tepi sungai, danau atau laut. Komposisi yang paling banyak terdapat pada pasir kuarsa adalah Silika dioksida $\left(\mathrm{SiO}_{2}\right)$ sebanyak 99,08\%. Pasir kuarsa merupakan komposisi gabungan dari $\mathrm{SiO}_{2}$, $\mathrm{Al}_{2} \mathrm{O}_{3}, \mathrm{CaO}, \mathrm{Fe}_{2} \mathrm{O}_{3}, \mathrm{MgO}, \mathrm{K}_{2} \mathrm{O}, \mathrm{Na}_{2} \mathrm{O}, \mathrm{S}, \mathrm{P}_{2} \mathrm{O}_{5}$, $\mathrm{TiO}_{2}, \mathrm{Cr}_{2} \mathrm{O}_{3}, \mathrm{MnO}_{2}$ (Sumarno et al, 2015). Oleh karena itu pasir kuarsa dapat digunakan sebagai alternatif bahan pengisi pada kompon karet, dapat menambah kekuatan ikatan yang terjadi pada komponen barang 
jadi karet, mengandung mineral utama, yaitu kuarsa dan feldspar.

Dalam pengolahan karet, silika adalah salah satu jenis bahan pengisi penguat non petroleum yang telah terbukti perannya sebagai bahan yang dapat menggantikan Carbon Black. Penggunaan silika harus diimbangi dengan penggunaan bahan pencepat pada saat vulkanisasi. Banyak jenis barang karet yang dapat dibuat dengan menggunakan bahan silika, yaitu produk ban, belt conveyor dan produk dengan spesifikasi khusus.

Berdasarkan karakteristik pasir kuarsa dan arang sekam padi tersebut, dalam penelitian ini akan dikaji sejauh mana pengaruh substitusi pasir kuarsa dan arang sekam padi terhadap kompon karet untuk bantalan dermaga sebagai pengganti bahan pengisi yang berasal dari bahan tambang, bahan galian atau dari tanah lempung. Pengaruh penggantian filler dipelajari dengan memvariasikan jumlah masing masing filler dengan ukuran mesh tertentu. Pengujian vulkanisat dilakukan untuk parameter kekerasan, tegangan putus, perpanjangan putus dan ketahanan sobek. Sebagai pembanding digunakan Persyaratan Mutu Vulkanisat karet kompon bantalan dermaga dengan SNI 06-3568-2006. Hasil penelitian ini diharapkan akan memberi informasi kepada masyarakat khususnya industri kompon karet, dimana penggunaan bahan filler non minyak bumi dapat dimanfaatkan untuk pembuatan kompon karet sehingga biaya produksi bisa ditekan tanpa mengurangi syarat mutu karet yang dihasilkan.

\section{BAHAN DAN METODE}

\section{Bahan}

Bahan-bahan yang digunakan dalam penelitian ini adalah compo 4, arang sekam padi 100 mesh, pasir kuarsa 100 mesh, 6 PPD, ZnO, asam stearat, sulfur, tetramethylthiuram disulfide (TMTD), Ncyclohexyl-2-benzothiazole Sulfenamide (CBS) dan N330.

\section{Peralatan}

Peralatan yang digunakan dalam penelitian ini adalah open mill L $140 \mathrm{~cm}$ D18 $\mathrm{cm}$ kapasitas $1 \mathrm{~kg}$, neraca analitis, timbangan metler p120 kapasitas 1200 g, glassware, timbangan duduk merek Berkel kapasitas 15 $\mathrm{kg}$, cutting scraf besar, alat press, cetakan sheet, gunting dan alat uji laboratorium.

\section{Rancangan Percobaan}

Penelitian dirancang dengan menggunakan 2 faktor, yaitu faktor konsentrasi arang sekam padi (A) dan konsentrasi partikel pasir kuarsa (B). Konsentrasi arang sekam padi 100 mesh $(A), A_{1}=40$ phr dan $A_{2}=50$ phr dan $A 3=60 \mathrm{phr}$, ukuran partikel pasir kuarsa (B): $B_{1}=40 \mathrm{phr}, B_{2}=50 \mathrm{phr}$ dan $B_{3}=60$ phr. Formula kompon bantalan dermaga yang digunakan dalam penelitian ini seperti tercantum pada Tabel 1.

\section{Tahapan Penelitian}

a. Pembuatan pasir kuarsa 100 mesh.

Pasir kuarsa dihaluskan dengan crusher, pasir kuarsa yang sudah hancur kemudian dipisahkan/diayak dengan menggunakan sieve shaker, dengan kecepatan $65 \mathrm{rpm}$ dan lama waktu pengayakan 20 menit, dengan ukuran partikel pasir kuarsa yang dihasilkan yaitu 100 mesh.

b. Pembuatan arang sekam padi 100 mesh

Sekam padi ditimbang, dimasukkan kedalam cawan porselen untuk dibakar, sekam padi dimasukkan ke dalam tanur/furnace untuk dijadikan arang dengan suhu $200^{\circ} \mathrm{C}$. Arang sekam padi yang dihasilkan diayak menggunakan sieve shaker dengan ukuran partikel yang dihasilkan 100 mesh

c. Pembuatan kompon karet (Thomas, 2005)

1. Persiapan bahan

Bahan kimia dari masing-masing formula kompon ditimbang sesuai dengan yang telah ditentukan. Jumlah dari setiap bahan didalam formula kompon dinyatakan dalam PHR (berat per seratus karet) dengan memperhatikan faktor konversinya.

2. Mixing ( pencampuran )

Proses pencampuran dilakukan dalam gilingan terbuka (open mill), yang 
telah dibersihkan. Selanjutnya dilakukan proses :

a). Mastikasi polimer (compo 4) selama \pm 5 menit.

b). Pencampuran bahan pengisi arang sekam padi, pasir kuarsa dan N330, potong setiap sisi sampai dua atau tiga kali selama \pm 6 menit.

c). Ditambahkan bahan penggiat/activator ( $\mathrm{ZnO}$ dan asam stearat) dan antioksidan (6 PPD, TMTD). Potong setiap sisi satu sampai tiga kali selama \pm 10 menit.

d). Ditambahkan accelerator (CBS), dipotong setiap sisi satu sampai tiga kali selama 10 menit.

e). Kompon dikeluarkan dari open mill dan ditentukan ukuran ketebalan lembaran kompon dengan menyetel jarak roll pada cetakan sheet, lalu dikeluarkan dan diletakkan diatas plastik transparan. Selanjutnya dilakukan master bed terhadap kompon \pm 24 jam.

f). Ditambahkan vulkanisator (sulfur) lalu dipotong setiap sisi satu sampai tiga kali selama \pm 10 menit.

g). Dilakukan prosedur ini untuk formula $A_{1}$ sampai dengan formula $B_{3}$.

Kompon karet yang dihasilkan diuji mutunya sehingga dapat diketahui kelemahan maupun kelebihannya. Parameter yang diuji yaitu kekerasan (shore A), tegangan putus (tensile strength) $\left(\mathrm{kg} / \mathrm{cm}^{2}\right)$, perpanjangan putus (elongation at break) $(\%)$ dan ketahanan sobek (tear resistance) $\left(\mathrm{kg} / \mathrm{cm}^{2}\right)$.

Tabel 1. Formula vulkanisat karet kompon bantalan dermaga SNI 06-3568-2006

\begin{tabular}{llcccccc}
\hline No & \multicolumn{1}{c}{ Bahan } & \multicolumn{7}{c}{ Formula (phr) } \\
\hline & & $\mathrm{A}_{1}$ & $\mathrm{~A}_{2}$ & $\mathrm{~A}_{3}$ & $\mathrm{~B}_{1}$ & $\mathrm{~B}_{2}$ & $\mathrm{~B}_{3}$ \\
\hline 1. & Compo 4 & 100 & 100 & 100 & 100 & 100 & 100 \\
2. & Arang sekam padi 100 & $\mathbf{4 0}$ & $\mathbf{5 0}$ & $\mathbf{6 0}$ & 0 & 0 & 0 \\
& mesh & & & & & & \\
3. & Pasir kuarsa 100 mesh & 0 & 0 & 0 & $\mathbf{4 0}$ & $\mathbf{5 0}$ & $\mathbf{6 0}$ \\
4. & 6PPD & 1 & 1 & 1 & 1 & 1 & 1 \\
5. & ZnO & 5 & 5 & 5 & 5 & 5 & 5 \\
6. & Asam stearat & 1 & 1 & 1 & 1 & 1 & 1 \\
7. & CBS & 1,3 & 1,3 & 1,3 & 1,3 & 1,3 & 1,3 \\
8. & TMTD & 0,2 & 0,2 & 0,2 & 0,2 & 0,2 & 0,2 \\
9. & Sulfur & 2,5 & 2,5 & 2,5 & 2,5 & 2,5 & 2,5 \\
10. & N330 & 5 & 5 & 5 & 5 & 5 & 5 \\
\hline
\end{tabular}

\section{HASIL DAN PEMBAHASAN}

Hasil pengujian kekerasan, tegangan putus, perpanjangan putus dan ketahanan sobek vulkanisat kompon karet hasil penelitian dibandingkan dengan Standar Syarat Mutu karet kompon bantalan dermaga SNI 06-3568-2006 seperti tercantum pada Tabel 2. 
Tabel 2. Hasil Uji Vulkanisat Kompon Karet

\begin{tabular}{|c|c|c|c|c|c|c|c|c|}
\hline \multirow{3}{*}{$\begin{array}{l}\mathrm{N} \\
\mathrm{O}\end{array}$} & \multirow[t]{3}{*}{ Sifat, Satuan } & \multirow{3}{*}{$\begin{array}{c}\text { Syarat mutu } \\
\text { SNI } \\
\text { 06-3568-2006 }\end{array}$} & \multicolumn{6}{|c|}{ Vulcanizates } \\
\hline & & & $A_{1}$ & $\mathrm{~A}_{2}$ & $\mathrm{~A}_{3}$ & $\mathrm{~B}_{1}$ & $\mathrm{~B}_{2}$ & $\mathrm{~B}_{3}$ \\
\hline & & & \multicolumn{3}{|c|}{ Arang Sekam Padi } & \multicolumn{3}{|c|}{ Pasir Kuarsa } \\
\hline 1. & Kekerasan & 50-80 Shore A & 54 & 55 & 55 & 54 & 55 & 57 \\
\hline 2. & Tegangan putus & Min 15 N/mm². & 16,48 & 15,2 & 14,22 & 16,67 & 16,57 & 13,24 \\
\hline 3. & $\begin{array}{l}\text { Perpanjangan } \\
\text { putus }\end{array}$ & Min $300 \%$ & 540 & 555 & 570 & 620 & 600 & 560 \\
\hline 4. & $\begin{array}{l}\text { Ketahanan } \\
\text { sobek }\end{array}$ & $\operatorname{Min} 70 \mathrm{~N} / \mathrm{mm}^{2}$ & 2,06 & 1,96 & 1,77 & 2,06 & 1,96 & 1,67 \\
\hline
\end{tabular}

\section{Kekerasan}

Uji kekerasan dilakukan untuk mengetahui besarnya kekerasan vulkanisat karet, dilakukan dengan kekuatan penekanan tertentu. Seperti yang ditunjukkan pada Gambar 1, nilai kekerasan tertinggi diperoleh pada formula $B_{3}$ yaitu 57 Shore $A$, dan nilai terendah pada formula $A_{1}$ dan formula $B_{1}$ yaitu 54 Shore A. Untuk nilai formula yang lain tidak menunjukkan kenaikan yang signifikan, nilai kekerasan relatif sama walau adanya perbedaan jenis dan jumlah bahan pengisi yang digunakan. Hal ini menunjukkan bahwa jumlah filler dan ukuran mesh arang sekam padi dan pasir kuarsa tidak memberikan nilai kekerasan yang berbeda. Namun demikian nilai kekerasan kompon disetiap formula masih memenuhi syarat mutu minimal SNI 06-3568-2006 yaitu 50 Shore A.



Gambar 1. Pengaruh Jumlah ASP dan Pasir Kuarsa Terhadap Kekerasan Karet Bantalan Dermaga 
Nilai kekerasan pada tiap perlakuan berbeda, hal ini disebabkan keberhasilan dispersi filler dalam matriks polimer, meskipun menggunakan ukuran partikel arang sekam padi dan pasir kuarsa 100 mesh dengan konsentrasi bahan pengisi mencapai 60 phr, masih tidak mampu menaikkan nilai kekerasan sampai maksimum. Hal ini menunjukkan bahwa arang sekam padi kurang berperan dalam proses reinforcing matriks polimer karet alam.

Menurut Liu et al, 2010 kekerasan adanya pengaruh optimasi penambahan bahan pengisi penguat yang meningkatkan kekerasan. Effek reinforcement arang sekam padi tidak seperti bahan carbon black atau bahan dari minyak bumi lainnya, hal ini diduga dalam penelitian ini morfologi arang sekam padi meliputi ukuran, porositas dan karakteristik permukaan yang tidak sama, sehingga tingkat dispersi dan kerataan dalam matriks polimer karet alam tidak baik. Namun arang sekam padi telah dapat mensubstitusi carbon black rneskipun belum dapat menyamai carbon black sebagai bahan penguat. Menurut Rattansom et al, 2009, penggunaan carbon black lebih efektif dalam mewujudkan kekerasan vulkanisat karet bila dibandingkan silika, dimana penggunaan silika memerlukan lebih banyak dua kali lipat dibanding penggunaan carbon black untuk menghasilkan nilai kekerasan yang sama.

\section{Tegangan Putus}

Berdasarkan Gambar 2 menunjukkan pengaruh jumlah bahan pengisi Arang Sekam Padi (ASP) dan pasir kuarsa terhadap tegangan putus vulkanisat kompon karet bantalan dermaga. Berdasarkan hasil pengujian, pada formula $B_{1}$ konsentrasi 40 phr pasir kuarsa dengan ukuran partikel 100 mesh diperoleh nilai tegangan putus kompon tertinggi yaitu $16,67 \mathrm{~N} / \mathrm{mm}^{2}$, sedangkan formula $\mathrm{B}_{3}$ konsentrasi $60 \mathrm{phr}$ pasir kuarsa dengan ukuran partikel 100 mesh diperoleh nilai tegangan putus kompon terendah yaitu $13,24 \mathrm{~N} / \mathrm{mm}^{2}$

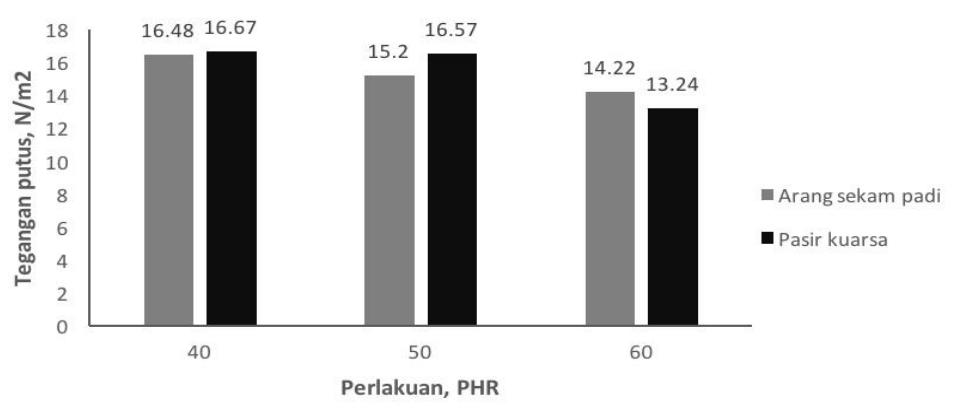

Gambar 2. Pengaruh Jumlah ASP dan Pasir Kuarsa Terhadap Tegangan Putus Karet Bantalan Dermaga

Pada Gambar 2 semakin tinggi konsentrasi pasir kuarsa dan ASP, tegangan putus kompon semakin turun. Namun, penurunan nilai tegangan putus dengan bahan pengisi pasir kuarsa tidak signifikan dan mencapai optimum pada konsentrasi 50 phr. Hal ini menunjukkan bahwa arang sekam padi belum mampu memberikan nilai tegangan putus yang optimal, sebaliknya bahan pengisi dari pasir kuarsa memberikan pengaruhnya tehadap karakteristik kompon karet, dimana bahan pengisi yang bersifat aktif merupakan bahan pengisi yang mampu meningkatkan sifat mekanik dari vulkanisat karet yang dihasilkan, hal ini dikarenakan secara teoritis pasir kuarsa mengandung $\mathrm{SiO}_{2}$ yaitu 60-98\% (Sukandarrumidi, 1999) dan Menurut Boonstra, (2005) $\mathrm{SiO}_{2}$ yaitu $97,13 \%$. Tegangan putus sangat erat bergantung pada nilai densitas sambung silang dan densitas cross linking dalam matriks polimer (Ismail et al, 2005). 


\section{Perpanjangan Putus}

Pengaruh jumlah dari bahan pengisi Arang Sekam Padi (ASP) dan pasir kuarsa terdapat pada Gambar 3. Nilai Perpanjangan putus kompon karet tertinggi dihasilkan dari konsentrasi pasir kuarsa 40 phr ukuran partikel 100 mesh yaitu $620 \%$, sedangkan yang paling rendah konsentrasi ASP $40 \mathrm{phr}$ ukuran partikel 100 mesh yaitu 540\%. Dapat dilihat nilai perpanjangan putus (\%) pada perlakuan yang menggunakan ASP cenderung naik dengan adanya penambahan konsentrasi ASP, namun menghasilkan nilai perpanjangan putus semakin menurun dengan penambahan pasir kuarsa.

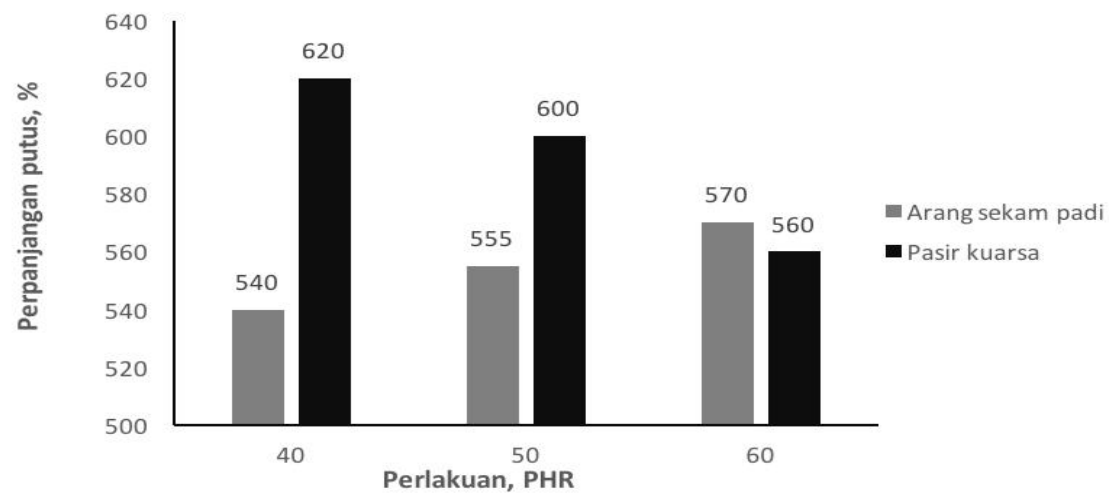

Gambar 3. Pengaruh Jumlah ASP dan Pasir Kuarsa Terhadap Perpanjangan Putus Karet Bantalan Dermaga

Dari hasil uji dapat dilihat bahan pengisi yang bersifat aktif sangat menentukan nilai vulkanisat karet yang dihasilkan, sehingga meningkatkan sifat mekanik dari vulkanisat karet. Hal ini dikarenakan pengaruh dari komposisi kimia yang terdapat pada bahan pengisi yang digunakan, dimana ASP mengandung $\mathrm{SiO}_{2}$ $(52 \%), \quad$ C $(31 \%), \quad K(0,3 \%), \quad N(0,18 \%), P$ $(0,08 \%)$ dan $\mathrm{Ca}(0,14 \%)$ (Kusmarwiyah dan Erni, 2011), Silika kristalin didapat dari sekam padi yang dibakar pada suhu $>1000^{\circ} \mathrm{C}$, diduga dapat mensubstitusi carbon black meskipun belum dapat menyamai fungsi carbon black sebagai bahan pengisi penguat (Bakri, 2008), hal ini dikarenakan jumlah carbon dari ASP sangat rendah yaitu 31\%, sehingga penggunaan arang sekam padi sebagai pengganti filler non minyak bumi densitas dan ikatan silang dalam polimer makin menurun.

ASP mempunyai ukuran partikel arang yang lebih besar, maka dispersinya kedalam matriks polimer tidak sebaik carbon black sehingga berpengaruh pada fluktuasi perpanjangan putusnya, namun fleksibilitas dari jaringan polimer yang disebabkan oleh terinkooporasinya arang sekam padi dengan struktur bercabang mengakibatkan effek elastis yang cukup tinggi (Susanto dan Daud, 2017). Carbon Black merupakan elemen karbon berbentuk koloidal yang terdiri atas 90-99\% karbon, sedang sisanya berupa elemen, non karbon yang terdiri atas Hidrogen, Oksigen dan Sulfur (Patel dan Brown, 1985).

Sedangkan pasir kuarsa senyawa makro yang dikandung yaitu $\mathrm{SiO}_{2}$ 60-98\% (Sukandarrumidi, 1999) dan $\mathrm{SiO}_{2}$ yaitu 97,13\% (Boonstra, 2005), Menurut Rattansom et al, (2009), penggunaan carbon black lebih efektif dalam mewujudkan kekerasan vulkanisat karet bila dibandingkan silika, dimana penggunaan silika memerlukan lebih banyak dua kali lipat dibanding penggunaan carbon black untuk menghasilkan nilai vulkanisat karet.

\section{Ketahanan Sobek}

Ketahanan sobek $\left(\mathrm{kg} / \mathrm{cm}^{2}\right)$ merupakan beban yang diperlukan untuk menarik sampai putus suatu potongan uji yang telah dilubangi memakai pons ditengah-tengah potongan uji sepanjang $5 \mathrm{~mm}$ tegak lurus 
pada arah tarik besarnya tenaga yang ditarik sampai putus.

Pada Gambar 4. Terlihat bahwa nilai ketahanan sobek kompon baik Formula $A_{1}$ sampai dengan Formula $\mathrm{B}_{3}$ tidak mampu mencapai angka optimal yang diharapkan dan semua nilai belum memenuhi standard yang dipersyaratkan Min $70 \mathrm{~N} / \mathrm{mm}^{2}$.

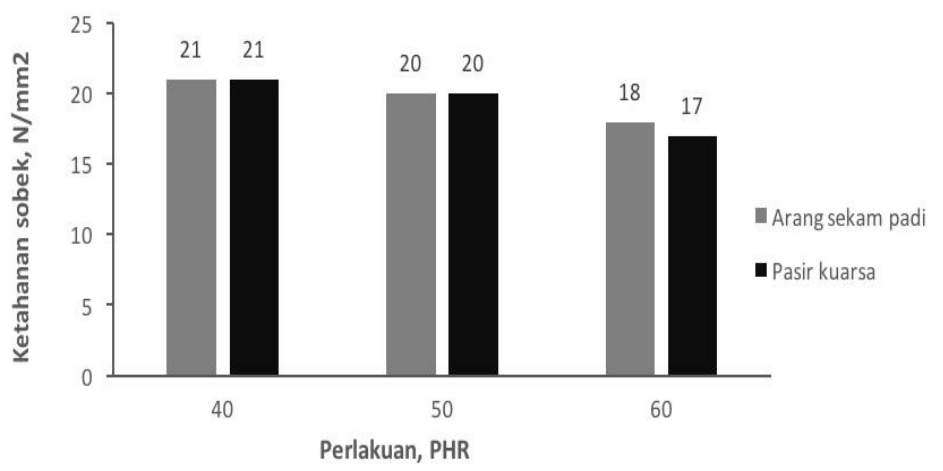

Gambar 3. Pengaruh Jumlah ASP dan Pasir Kuarsa Terhadap Ketahanan Sobek Karet Bantalan Dermaga

\section{KESIMPULAN}

Berbeda dengan penjelasan sebelumnya, tingginya nilai ketahanan sobek merupakan cerminan tingginya energi pemutusan polimer karena densitas ikatan silang yang optimum dan tingkat kerapatan polimer dan bahan pengisi (Fang et al, 2014; Zhang et.al, 2010). Dari gambar 4 terlihat bahwa nilai ketahanan sobek tidak mengalami kenaikan seiring dengan naiknya jumlah bahan pengisi ASP dan Pasir Kuarsa. Apabila penambahan arang sekam padi dilanjutkan maka ketahanan sobek cenderung turun. Hal ini disebabkan kurang aktifnya luas permukaan dari arang sekam padi yang terkait dengan kurang sempurnanya proses pembakaran sehingga kemungkinan masih ada tersisa yang menempel pada permukaan. Nilai ketahanan sobek akan meningkat dengan peningkatan ukuran partikel bahan pengisi dan luas permukaan (Haghigat et al, 2005; Monchai et al, 2012). Peningkatan jumlah bahan pengisi ASP dan pasir kuarsa tidak mampu menaikkan nilai ketahanan sobek tanpa memvariasikan ukuran partikel.
Bahan pengisi yang bersumber dari arang sekam padi dan pasir kuarsa dapat berfungsi sebagai substitusi alternatif yang ramah lingkungan dari bahan pengisi minyak bumi. Nilai sifat fisik vulkanisat karet terbaik terdapat pada variasi konsentrasi ASP dan pasir kuarsa 40 phr, dimana vulkanisat karet yang dihasilkan memenuhi syarat karet kompon bantalan dermaga SNI 06-3568-2006 untuk parameter kekerasan, tegangan putus dan perpanjangan putus. Penambahan arang sekam padi dan pasir kuarsa cenderung menurunkan sifat tegangan putus, ketahanan sobek dan menaikkan sifat kekerasan, perpanjangan putus. Bahan pengisi ASP dan pasir kuarsa digunakan pada industri karet untuk meningkatkan interaksi bahan pengisi dengan karet, sehingga dapat meningkatkan sifat fisik vulkanisat karet. Pengembangan industri barang jadi karet memiliki potensi yang sangat besar mengingat besarnya potensi bahan baku, peluang pasar dan kemampuan SDM yang dimiliki. 


\section{UCAPAN TERIMA KASIH}

Penulis mengucapkan terima kasih kepada Kepala Baristand Industri Palembang atas fasilitas pelaksanaan penelitian, Bapak Ahmad Fadil, Bapak Isa, Bapak Fiqih yang telah membantu kegiatan penelitian. Bapak/lbu reviewer dan editor jurnal atas masukan yang telah diberikan untuk penyempurnaan tulisan ini.

\section{DAFTAR PUSTAKA}

Bakri (2008). Komponen kimia da fisik abu sekam padi sebagai scm untuk pembuatan komposit semen. Perennial, 5(1), 9-14, http://doi.org/10.1016/j.combuildmat.200706. 01.

Boonstra BB. (2005). Reinforcement by filler. J Rubber Age. 92 (6): 227-235.

BSN. (2004). SNI 06-3568-2006. Syarat Mutu Vulkanisir Karet kompon bantalan Dermaga. Indonesia: Badan Standardisasi Nasional.

Chandra, A., Miryanti, A., Widjaya, L.B. dan Pramudita A, (2012). Karakterisasi Silika dari Sekam Padi. Laporan Penelitian Lembaga Penelitian dan Pengabdian kepada Masyarakat Universitas Katholik Parahiyangan Bandung.

Fang, Y., M. Zhan, and Y. Wang (2014). Investigation of dynamic characteristic of nano-size calsium carbonateadded in natural rubber vulcanizate. Composites Part B. Engineering.60: p.561-567

Frochlich, J.,W, Niedermeier, and H,D. Luginsland, (2005).The Effect of filer filler and filler elastomer interaction on rubber reinforcement. Composites Part A. Applied Science and Manufacturing, 36 (4): p.449460

Fu, S-Y., (2008). Effects of particle size, particle/matrix interface adhesion and particle loading on mechanical proprties of particulate-polymer coposites. Composites Part B: Engineering, , 39(6): p.933-961

Hadi, Suratman., Munasir, T (2010). Sintesis Silika Berbasis Pasir Alam Bancar Menggunakan Metode Kopresipitasi, 1-5. http://doi.org/10.12962/j24604682.v7i2.902.

Haghighat, M.A., Khorasani,S.N.M and Zadhoush. (2007). Filler-Rubber Interaction In A Celulose-Filled Styrene Butadiene ubber Composites. Journal of Applied Polymer Science. 10:748-754.
Hong, Z., Liu, A., \& Chen, L. (2009). Preparation of Bioactive Glass Ceramic Nanoparticles by Combination of Sol- Gel and Co-precipitation Method. Non-Crystalline Solids, 355(6), 368-372.

Ismail, H., A. Rusli, and A. Rashid, (2005). Maleated Natural Rubber as a coupling agent for paper sludge filled natural rubber composites. Polmer Testing, 24(7):P. 856862

Kusmarwiyah R dan Erni S. (2011). Pengaruh media tumbuh dan pupuk organik cair terhadap pertumbuhan dan hasil tanaman seledri (Apium graveolens L.). Jurnal Crop Agro. 4 (2): 7-12.

Lazzeri, A., Y., Thio, and R. Cohen, (2004). Volume strain measurements on $\mathrm{CaCO}_{3}$ polypropylenen particulate composites: the effect of particle size. Journal of applied polymer science, 91(2): p.925-935

Leblanc, J.L, (2002). Rubber-filler interaction and theological properties in filled compounds. Progress in polymer science. 27(4): p,. 627687

Liu, C., Y. Shao, and D. Jia, (2010). Chemically modified starch reinforced natural rubber composites Polimer. 49(8): p.2176-2181

Marlina, P., Rahmaniar, dan Raimon. (2011). Nanokomposit silika karbida sebagai filler dalam pembuatan kompon ban luar kendaraan bermotor roda dua. Jakarta

Mor, S., Chodden, K., and Ravindra, K (2016), Application of agro-waste rice husk ash for the removal of phosphate from the waste water. Journal of Cleaner Production, 129, 673-680.

http://doi.org/10.1016/j.jclepro.2016.03.088

Nan, C.-W., Y. Shen, and J. Ma. (2010). Physical properties of composites near percolation. Annual Review of Materials Research. 40:p, 131-151

Nozawa, K., Gailhanou, H., Raison, L., Panizza, P., Ushiki, H., Sellier, E.,Delville, M. H. (2005). Smart control of monodisperse stober silica particles: Effect of reactant addition rate on growth process. Langmuir, 21(4), 1516-1523. http://doi.org/10.1021/la048569r.

Patel, A.C and WA, Browm, 1985, Csrbon black stucture and viscoelastic properties of Rubber Coumpounds A. presented The Rubber Divisions American Chemical Society, 127 th meeting Los Angeles, Califomia April13-26, 
Putro, A.L., dan D. Prasetyoko, (2007). Abu Sekam Padi sebagai sumber silika dan sintesis zeolite ZSM-5 tanpa menggunakan templat organik. Akta Kimindo. 3(1): p.33-36.

Rahmaniar dan Nuyah. (2016). Pemanfaatan pasir kuarsa sebagai bahan pengisi dalam pembuatan karpet karet. Jurnal Dinamika Penelitian Industri, 27(2).

Rattanasom, N., Prasertsri, S., Ruangritnumchai, T. (2009). Comparison of the mechanical properties at similar hardness level of natural rubber filled with various reinforcing - fillers. Journal of Polymer Testing, 28(1), 8-12. http://doi.org/10.1016/j.polymertesting.2008. 08.004 .

Susanto, T., Daud, D,. (2017). Pengaruh penggantian carbon black menggunakan bahan pengisi non minyak bumi terhadap kualitas kompon karet sol sepatu. Prosiding Seminar Nasional Riset Industri III Tahun
2017. Baristand Industri Bandar Lampung

Sukandarrumidi, (1999), Bahan Galian Industri, Edisi I, Gadjah Mada University Press, Yogyakarta

Thomas. (2005). Disain Kompon. Bogor: Balai Penelitian Teknologi Karet Bogor.

Yuniari, A. Lestari, S.B.P (2003). Arang aktif sekam padi sebagai bahan pengisi kompon sol karet. Majalah karet, kulit dan plastic. Vol 19 No 1.

Zhang, A., Chen, S., Li, Z., (2010). Study on mechanical anf flow properties of acrylonitebutadiene-styrene/poly(methyl

methacrylate)/nano calcium carbonate composites. Polymer composites. 31(9): p.1593-1602 